\title{
Innovation of University Library Subject Service
}

\author{
Maoli Xu \\ Library \\ Jilin Agricultural University \\ Changchun,,China \\ 729738677@qq.com \\ +8615604305161
}

\begin{abstract}
The launch of the service is subject to deepen the university library services in the new situation, the need for service innovation . The article connotations service discipline, form, characteristics and optimization measures such as University Library Subject Service discussed.
\end{abstract}

Keywords - university library ; discipline services ; Subject Librarian

\section{INTRODUCTION}

Library Subject Service is a new service model and service mechanism to provide strong protection for the innovation of information science . Conduct subject service is an important means to enhance library services ability to change service effectiveness, reshape its image. This article is based on hands- on , on the subject of university library information services for further discussion .

\section{THE MEANING OF THE SUBJECT SERVICE}

Subject Service is a collection of physical resources and network -based virtual resources to user needs and goal-driven , process -oriented research, into the decision-making process and help users find the user or the formation of value-added solutions to service issues. Service is subject disciplines, knowledge, personality into service purpose, content ontology tacit knowledge , knowledge mining, restructuring and expansion activities , resources or knowledge services information services E-Science Environment .

Unlike focusing on the acquisition and transfer of information resources, providing only specific information , data or documents of traditional services, subject service is diverse and dynamic resource integration services provide a distributed system is a professional and personalized service $^{[1]}$. Meanwhile, the subject service is a high knowledge content services, reflects the innovative work of staff, can bring added value. It stressed that according to user needs, developed new products with unique value knowledge to help users solve problems or provide solutions.

\section{IN THE FORM OF SUBJECT SERVICE}

\section{A. full implementation services for research projects}

Involved in the whole process of research, information and services anywhere, anytime to understand the needs of users, the demand for timely feedback to the relevant departments, propose solutions and implement solutions, and supervise the entire program monitoring problem solving . Different information needs at different stages of research should be to carry out targeted services according to the characteristics of the different stages . If the project establishment phase, the timely collection of the professional background, Review of research progress . In topics, stage , providing experimental research programs around the progress , data analysis, research progress and dynamics. In the final stage of the subject, a comparative study, the new investigation, contributors and other services. On the development of new products and patent magnetic field competitive analysis ; assessment report on the project award, new research evaluation conducted searches and citation analysis .

\section{B. Participate in service learning activities}

Cooperation with professional teachers, participate in teaching activities and classroom discussions, such as teaching reference materials are used, intended for undergraduate teaching reference books, reference intended for graduate students, for college students writing papers provide information on aspects of academic guidance documents provide the title of the research project reports and SDI services ${ }^{[2]}$. In addition can also improve the level of teaching and academic research, the development of academic exchanges and education provide useful help , such as the provision of textbooks among other reference resources to improve teaching methods and learning methods, students learn skills, new technology and the introduction of new research teaching. Reference services to carry out e-learning for teachers to create Web pages , multimedia image processing, a variety of courseware development to provide support to service in teaching and research . With digitization and digital campus teaching process, teachers and curriculum needs to provide the appropriate characteristics , personalized information services.

\section{Conduct intelligence research subjects}

Higher goal of discipline is to carry out service discipline intelligence research , further to provide users with expert advisory services, build knowledge-based services, and promote knowledge into productivity. Discipline intelligence research is based on the specific needs of researchers, the complexity of the information content and depth to reveal 
the intrinsic relationship , correlation analysis and knowledge performance. Topics intelligence services to provide researchers, including writing thematic research reports, technical reports hotspot disciplines, special projects, such as the pre- investigation report . Provide decision-making services including domestic and international research institutions and R \& D capabilities to compete for the research object decision makers, R \& D output, analysis and evaluation of future development trends, technological innovation and other aspects of the contribution $^{[3]}$.

\section{Establish institutional repository system}

Actively assist teachers and students put their academic and teaching resources electronically ( papers, technical reports, research data , teaching materials, etc. ) stored in the knowledge base, and actively establish a standard storage processes, management mechanisms and technical procedures, and actively into the vertebral open access to resources, the initiative to undertake long-term preservation of these data the responsibility to become the school's knowledge assets organizers, managers and depositaries .

\section{THE SUBJECT SERVICE FEATURES}

\section{A. subject service initiative}

Now, with the gradual deepening of the subject service to carry out, the university 's disciplinary service users need to continue with the formation of a more standardized and improve the organization and management system, such as the initiative to establish a powerful sense of participation , active with various academic departments librarians and other subjects through face to face communication , mutual email, forums and other organizations subject librarian extensive variety of ways to communicate .

\section{B. professional service disciplines}

University Library Services will be subject to the specific subject area expertise , or to organize or implement service -oriented research process -oriented teaching, learning , research tasks, specific problems of user-oriented , product design and development of personalized information and support based on the user's personal demand service selection , to carry out disciplinary and specialized services $^{[4]}$. To improve the depth and quality of services through specialization, in order to achieve better results service .

\section{C. the value of the subject service}

University Library provides the main subject service is subject librarians, academic librarians and value-added services include three levels: to help users solve problems, provide solutions to the user directly to the problem , for users to solve their knowledge and abilities that can not be solved problems. Subject Librarians will extract the information , integration, innovation, integrated core competencies for the knowledge can be directly applied to provide effective , high knowledge content services , thereby improving the efficiency of knowledge innovation and user application knowledge of the user's knowledge innovation activities significant, even critical impact, which is based on the survival of subject Librarian System target lies.

\section{D. convenience and fast service of disciplines}

With the rapid development of information technology and the Internet change the environment, forming a space for information sharing between the various universities, colleges and universities by reconfiguring the physical space of the library, integration services and research methods, and establish a new, more mature the discipline of the service model. University Library use this powerful discipline information sharing resource sharing and interlibrary loan services do support network to do the leading subject of librarians in hardware and management systems to provide users with a large number of subjects can be quick and easy access to information, so that readers get a very fast service.

\section{MEASURES TO OPTIMIZE SUBJECT SERVICE}

\section{A. strengthening discipline service team building}

Disciplinary service team building, discipline is the key security resource development for sustainable development. As the editorial staff, especially the post subject librarian particularity requirement that they must fully grasp the knowledge and the provisions of the Library , Information Resources proficiency counterparts disciplines. Therefore, strengthening the ability of team members teaching, public relations skills, language skills and IT are subject librarian indispensable basic skills. In addition, the effectiveness of coordination between team members is also crucial subject service, but also paid special attention to the close cooperation between the members support each other, work together to be responsible for the customer service front line ${ }^{[5]}$.

\section{B. constructed stepped Subject Librarian service model}

The so-called ladder is the subject librarian service model, based on the nature of the subject librarian subjects divided into themes : science librarian, librarians and social science disciplines of engineering disciplines librarian three categories. Each category subject librarian with three different types of librarians : preliminary type librarian, service-oriented librarian, research subject librarian . Type of subject librarians should prepare with strong communication skills and coordination, its focus is on faculty liaison ; service-oriented subject librarian should have a strong sense of information, information retrieval capabilities and a high level of foreign language, whose main work is responsible for collecting, sorting network information resources related disciplines to develop a variety of databases to help users thematic literature search related topics to help users improve retrieval skills ; research subjects who should have creative thinking and a high level 
of scientific research, which focus is on providing research services, such as decision-making services, personalized services, SDI services.

\section{C. to strengthen the discipline of service evaluation}

University Library Services to establish a scientific discipline evaluation system, the evaluation should include: service systems, service process, answer quality , customer satisfaction , service statistics, and services to measure the cost of openness . Adhere to the principles of scientific evaluation of qualitative and quantitative, to develop different evaluation methods for different services, but also to develop a comprehensive evaluation of the entire service process of the steps .

\section{CONCLUSIONS}

In short, the university library only through in-depth research needs of readers, and explore the subject in depth understanding of the role of services in the construction of university library information resources in order for readers to build a development adapted to their personalized information environment, compared to the full enjoyment of the reader the previously unimaginable new service model to bring their services

\section{REFERENCES}

[1] Wu Liping . Factors discipline of university library services and the development of countermeasures [J]. Modern intelligence , 2009,29 ( 3 ) :100- 103

[2] Xiaqiu Ping Situation Analysis and Development Research Knowledge Services University Library disciplines [J] Modern Intelligence , 2010, ( 1 ) : $93 \sim 95$.

[3] Jing Chu Li , Zhang Dongrong. Second generation of subject librarians and academic services [J]. Library and information work , 2008 ( 2 ) :6 -10 .

[4] Xia Yanyan. Establishment and development of Subject Librarian System [J] Agricultural Library and Information Sciences , 2010, ( 6 ) : 289 - 292.

[5] Wang Min. Talk about the role of subject librarians in discipline construction [J] Sci-Tech Information Development \& Economy , 2010, ( 1 ) : $28 \sim 29$. 